\title{
Motivasi Pemuda Tani Bekerja di Sektor Pertanian di Pekon Padang Cahya Kecamatan Balik Bukit Kabupaten Lampung Barat
}

\section{Motivation of Youth Farmers to Work in Agricultural Sector in Padang Cahaya Village, Balik Bukit Sub-district, West Lampung Regency}

\author{
Oleh: \\ Rabyatul Hadawiyah $^{{ }^{*}}{ }$, Indah Nurmayasari ${ }^{1}$, dan Begem Viantimala ${ }^{1}$ \\ Program Studi Penyuluhan Pertanian, Fakultas Pertanian, Universitas Lampung \\ Jl. Prof. Dr. Soemantri Brojonegoro No. 1 Bandar Lampung 35145, Lampung, Indonesia. \\ *e-mail: rabyatulhadawiyah05@gmail.com
}

Received: March 06 2021; Revised: May 21, 2021; Accepted June 30, 2021

\begin{abstract}
ABSTRAK
Menurunnya jumlah tenaga kerja di sektor pertanian merupakan ancaman bagi keberlangsungan pembangunan pertanian. Partisipasi pemuda di bidang pertanian sangat dibutuhkan. Tujua penelitian ini adalah mengetahui tingkat motivasi pemuda tani untuk bekerja di sektor pertanian dan faktoR apa saja yang berhubungan dengan motivasi mereka. Penelitian dilakukan di Desa Padang Cahaya Kecamatan Balik Bukit Kabupaten Lampung Barat. Ada 72 responden pemuda yang bekerja di bidang pertanian dan diwawancarai menggunakan kuesioner terstruktur. Data dianalisis secara deskriptif. Berdasarkan penelitian tingkat motivasi pemuda tani untuk bekerja di sektor pertanian termasuk dalam kategori tinggi. Faktor yang berhubungan dengan motivasi mereka bekerja di bidang pertanian adalah pendidikan, pendapatan, dan luas lahan.
\end{abstract}

Kata kunci: Motivasi, Pemuda tani, Pendidikan

\section{ABSTRACT}

The decreasing number of workforce in agricultural sector is a threat to the sustainability of agricultural development. The participation of youth in agriculture is needed. The analys of the research are to find out the level of motivation of youth farmers to work in agricultural sector and factors related to their motivation. The study is counducted in Padang Cahaya Village, Balik Bukit Subdistrict of West Lampung Regency. Respondents were 72 the resech indicated that motivation level of youth farmers working youths working on agriculture and interviewed using structured questionnaires. Data were analyzed descriptiveliy. The results showed that agricultural sector belongs to high category. Factors related are education, income, and land size

Keywords: Motivasion, Youth farmer, Education,

\section{PENDAHULUAN}

Indonesia merupakan negara dengan mayoritas penduduk yang memiliki mata pencarian pada sektor pertanian sehingga sektor pertanian mampu menyerap tenaga kerja cukup besar. Pembangunan subsektor pertanian diarahkan untuk meningkatkan produksi pertanian guna memenuhi kebutuhan pangan, kebutuhan industri dalam negeri, meningkatkan kebutuhan ekspor, meningkatkan produktivitas pendapatan petani, memperluas kesempatan kerja dan pemerataan kesempatan berusaha khususnya di bidang pertanian. 
Corak pertumbuhan ekonomi di setiap daerah memiliki perbedaan antara satu daerah dengan daerah lain disebabkan oleh perbedaan potensi sumber daya yang dimiliki. Salah satu sumber daya yang paling utama adalah sumber daya manusia atau tenaga kerja. Badan pusat statistik (2018) menunjukkan adanya kecendrungan penurunan tenaga kerja di sektor pertanian pada usia angkatan kerja.

Keterlibatan sebagian besar tenaga kerja pertanian dalam keadaan setengah terpaksa dalam menjalankan pekerjaannya mengakibatkan proses produksi pertanian menjadi kurang optimal. Hal ini pada gilirannya akan mengakibatkan penurunan produktivitas tenaga kerja. Jika hal tersebut terjadi secara berkelanjutan maka akan menghambat perkembangan sektor pertanian itu sendiri.

Dampaknya sudah jelas, mulai dari perekonomian masyarakat petani pedesaan hingga ketersediaan kebutuhan dasar dipastikan akan terancam. Nugroho, Waluyati dan Jamhari (2018), mengemukakan faktor pendorong pergeseran generasi muda dari sektor pertanian ke sektor non pertanian antara lain pendapatan di luas sektor pertanian, image negatif pertanian, peningkatan pendidikan, dan kepemilikan lahan pertanian yang sempit. Faktor penarik generasi muda ke sektor pertanian antara lain finansial, warisan orang tua, dan insentif pemerintah.

Lampung merupakan provinsi yang penduduknya bergantung pada hasil pertanian. Kabupaten Lampung Barat memiliki peranan tertinggi kedua setelah Kabupaten Pesisir Barat dalam sektor pertanian, kehutanan, dan perikanan sejak tahun 2013 sampai dengan tahun 2017. Hal ini karena potensi Kabupaten Lampung Barat memiliki keunggulan di bidang pertanian seperti tanaman perkebunan, sayuran, dan pangan. Misalnya saja produksi kopi sebesar 52.543 ton, kayu manis sebesar 451 ton, dan lada 3.093 ton pada tahun 2014. Sedangkan Kabupaten Pesisir Barat hanya unggul pada sektor perikanan saja (Badan Pusat Statistik, 2018).
Kecamatan Balik Bukit memiliki luas lahan paling luas dan jumlah penduduk paling banyak yaitu sebesar 1.756 .300 ha dan 38,264 jiwa. Terkait dengan potensi sumber daya alam dan sumber daya manusia yang dimiliki maka penting diketahui motivasi pemuda tani bekerja di sektor pertanian. ketertarikan pemuda tani di Pekon Padang Cahya pada sektor pertanian merupakan hal yang penting bagi kelanjutan pertanian di masa yang akan datang. Sehubungan dengan hal ini maka dilakukan penelitian dengan judul motivasi pemuda tani bekerja di sektor pertanian di Pekon Padang Cahya, Kecamatan Balik Bukit, Kabupaten Lampung Barat.

\section{METODE PENELITIAN}

Penelitian ini dilakukan dengan metode survey. Menurut (Sugiyono, 2010) metode survey merupakan metode yang digunakan pada penelitian atau pengamatan secara langsung baik dalam populasi jumlah besar atau kecil. Metode pengambilan responden dilkukan secara sengaja (purpossive sampling) sebanyak 72 orang responden pemuda tani laki-laki dan perempuan yang berumur 15-30 tahun.

SSumber data yang digunakan berupa data primer dan data sekunder. Data primer merupakan data yang diambil secara langsung dari responden. Data sekunder diperoleh dari loporan-laporan tertulis serta informasi tentang keadaan lokasi penelitian.

Lokasi penelitian dipilih berdasarkan luas lahan paling luas yang ada Kecamatan Balik Bukit, di antara kecamatan lainnya yang terdapat di Kabupaten Lampung Barat dan Pekon Padang Cahya merupakan pekon yang paling banyak jumlah penduduk yang berkerja di sektor pertanian. Penelitian dilaksanakan pada bulan Agustus 2019.

Metode pengambilan sampel dilakukan secara sengaja (purpossive sampling) sebanyak 72 orang responden pemuda tani laki-laki dan perempuan yang berumur 15-30 tahun. Variabel dalam penelitian terdiri dari variabel bebas dan variabel terikat yaitu variabel bebas (variabel $\mathrm{X}$ ) meliputi: 
pendidikan (X1), pendapatan (X2), luas lahan (X3), status kepemilikan lahan (X4), dan jarak tempat tinggal ke pusat kota (X5) sedangkan variabel terikat (variabel $Y$ ) adalah motivasi pemuda tani bekerja di sektor pertanian. Pengukuran variabel $\mathrm{X}$ dan $\mathrm{Y}$ dilakukan dengan teknik skoring paling tinggi 3 paling rendah 1 .

Metode analisis data menggunankan analisis deskriptif, sedangkan pengujian hipotesis menggunakan statistik non parametrik korelasi rank spearman (Siegel 2011). Kaidah pengambilan keputusan dalam penelitian ditentukan dengan menggunakan aplikasi SPSS Versi 25. Kaidah pengambilan keputusan sebagai berikut:

1. Bila nilai signifikansi $\leq(\alpha)=0,05$ atau $(\alpha)$ $=0,01$ maka terima $\mathrm{H} 1$, artinya terdapat hubungan yang signifikan antara satu variabel independen dengan variabel dependen.

2. Bila nilai signifikansi $>(\alpha)=0,05$ atau $(\alpha)$ 0,01 maka tolak $\mathrm{H} 1$, artinya terdapat hubungan yang signifikan antara satu variabel independen dengan variabel dependen.

Pengukur ketepatan kuesioner penelitian menggunakan uji validitas dan uji reabilitas. Validitas adalah ketepatan atau kecermatan dalam instrumen pengukuran sedangkan reabilitas artinya dapat dipercaya, artinya instrumen dapat memberikan hasil yang tepat. Uji ini dilakukan untuk melihat kesesuaian nilai dari sebuah kuesioner yang dikerjakan oleh seorang responden pada kesempatan atau waktu yang berbeda dan dengan kuesioner yang sama. Relibilitas suatu pengukuran juga menunjukkan sejauh mana pengukuran tersebut dilakukan secara baik atau bebas dari error.

Menurut Natanael (2013), nilai validitas dapat dikatakan baik jika nilai corrected item dari total correlation bernilai lebih dari 0,2 dan variabel yang dikatakan reliabilitas jika nilai cronback alpha> 0,6. Hasil uji validitas dan reabilitas pada kuesioner penelitian ini didapatkan sebanyak 18 butir soal berada di atas $0,2(0,332-0,874)$ yang artinya soal tersebut valid. pertanyaan motivasi pemuda tani dinyatakan reliabel, karena nilai Cronbach's Alpha lebih dari 0,60 .

\section{HASIL DAN PEMBAHASAN}

\section{Karakteristik Responden}

Jenis kelamin pemuda tani yang tertinggi dalam penelitian ini yaitu laki-laki berjumlah (58\%). Artinya laki-laki lebih tertarik dalam melakukan pekerjaan di sektor pertanian untuk memenuhi kebutuhan rumah tangga.

Usia responden paling banyak berumur antara 22-25 tahun sebesar (58\%). Umur responden dalam penelitian ini berada pada kategori produktif untuk bekerja. Pemuda tani dalam memilih pekerjaan di tentukan oleh ada atau tidak adanya pekerjaan yang di kehendaki dan di tentukan oleh imbalan yang akan diterima oleh responden. Identitas responden dapat dilihat pada Tabel 1 dan 2 .

Tabel 1.

Identitas responden berdasarkan jenis kelamin dan umur

\begin{tabular}{lcc}
\hline Identitas responden & $\begin{array}{l}\text { Responden } \\
\text { Jumlah }\end{array}$ & (\%) \\
\hline Jenis kelamin & & \\
\hline Laki-laki & 42 & 58 \\
Perempuan & 30 & 42 \\
\hline Umur & & \\
\hline $16-21$ & 14 & 19 \\
$22-25$ & 42 & 58 \\
$26-30$ & 16 & 22 \\
\hline
\end{tabular}

Tabel 2.

Karakteristik responden berdasarkan pekerjaan utama dan pekerjaan sampingan

\begin{tabular}{llcc}
\hline $\begin{array}{l}\text { Pekerjaan } \\
\text { Utama }\end{array}$ & $\begin{array}{c}\text { Pekerjaan } \\
\text { Sampingan }\end{array}$ & $\begin{array}{c}\text { Jumlah } \\
\text { (Orang) }\end{array}$ & $\mathbf{( \% )}$ \\
\hline Petani & Pedagang & 5 & 7 \\
& Pekerja & 2 & 3 \\
Petani & Bangunan & & 2 \\
Petani & Buruh Tani & 1 & 2 \\
Petani & - & 64 & 88 \\
Jumlah & & 72 & 100 \\
\hline
\end{tabular}


Responden yang memiliki pekerjaan sampingan pedagang berjumlah $(7 \%)$, pemuda tani dengan status pekerjaan sampingan bekerja sebagai pekerja bangunan (3\%). Responden dengan pekerjaan sampingan buruh tani sebesar (2\%), dan yang tidak memiliki pekerjaan sampingan (88\%), artinya responden lebih tertarik bekerja di bidang sektor pertanian di bandingkan dengan sektor di luar sektor pertanian dikarenakan bekerja di sektor pertanian tidak banyak resiko yang ditanggung oleh pemuda petani. Status pernikahan pemuda tani dikelompokkan dalam dua kelompok yaitu menikah dan belum menikah. Jumlah pemuda tani yang sudah menikah berjumlah (61\%) dan belum menikah (39\%).

\section{Variabel (X) yang Berkorelasi dengan Motivasi Pemuda Tani(X)}

\section{Pendidikan $(X 1)$}

Latar belakang dapat mempengaruhi perilaku seseorang. Hal ini dapat diartikan pemuda tani dalam memilih pekerjaan dipengaruhi latar belakang pendidikannya. Seseorang yang memiliki tingkat pendidikan formal yang tinggi pada umumnya memiliki karakter yang berbeda dengan orang yang memiliki pendidikan rendah dalam mencari pengetahuan yang baru untuk melakukan kegiatan ekonomi demikian pula pendidikan menjadi modal dalam memilih pekerjaan. Tingkat pendidikan dapat mempengarui pemuda petani dalam menerima informasi, mengadopsi teknologi, dan menerapkan inovasi.

Hasil penelitian menunjukkan pendidikan sebagian besar SMA dengan jumlah (42\%). Pendidikan responden yang tinggi disebabkan karena di daerah penelitian akses terhadap pendidikan formal sangat memungkinkan serta didukung peraturan pemerintah wajib belajar 12 tahun. Hal ini mempermudah responden dalam menyerap pengetahuan dan inovasi yang berkaitan terhadap kemajuan sektor pertanian.

\section{Pendapatan Rumah Tangga (X2)}

Pendapatan merupakan penerimaan atau hasil produksi yang dikalikan dengan harga jual dikurangi biaya produksi. Penelitian ini menghitung pendapatan utama dan sampingan. Berdasarkan hasil penelitian pendapatan pemuda tani paling banyak di klasifikasikan rendah dengan pendapatan sebesar Rp 7.000.000 sampai Rp 24.906.667.

Pendapatan termasuk dalam kategori rendah namun petani tetap melakukan kegiatan usahataninya dikarenakan daerah penelitian yang jauh dari pusat kota sehingga tidak banyak alternatif lain untuk bekerja di luar sektor pertanian serta kegiatan usahatani kopi relatif mudah untuk diusahakan. Hal ini sejalan dengan pendapat yang dikemukakan Hasanuddin dan Viantimala (2011), yang menyatakan kemudahan aspek budidaya memiliki hubungan dengan motivasi pemuda petani dalam mengusahakan suatu komoditas usahatani.

Meskipun pendapatan responden rendah namun mampu memenuhi kebutuhan dasar seperti pangan. Pemenuhan kebutuhan akan pangan petani dapat diperoleh dari menanam padi di sawah, lauk dari berternak atau memelihara ikan, dan sayuran ditanam di pekarang rumah atau di kebun yang dimiliki oleh responden, sedangkan sandang dan papan dapat diperoleh dari hasil tanaman yang dijual misalnya responden bekerja sebagai petani kopi atau sayuran. Hasil penjualan akan digunakan untuk memenuhi kebutuhan sandang dan papan dengan pendapatan responden yang rendah responden tetap bertahan bekerja di sektor pertanian.

\section{Luas Lahan (X3)}

Luas lahan adalah tempat melakukan kegiatan usahatani, semakin luas lahan yang digunakan maka semakin tinggi tingkat produksi dan produktivitas yang dihasilkan dalam kegiatan usahatani dalam satuan hektar (ha). Pemuda tani bergantung pada luas lahan yang dimilikinya untuk memenuhi kebutuhan hidupnya. 
Hasil penelitian menunjukkan sebagian besar responden memiliki luas lahan yang tergolong sempit (32\%). Ini berarti dengan lahan yang tergolong sempit responden mampu memaksimalkan produktivitas tanaman mereka agar dapat memenuhi kebutuhan hidup mereka nantinya.

\section{Status Kepemilikan Lahan (X4)}

Status kepemilikan lahan yaitu hak atas tanah yang diusahakan oleh petani dalam menjalankan usahatani. Lahan yang berstatus milik sendiri memiliki kekuasaan yang tinggi bagi petani dikarenakan petani memiliki hak penuh atas tanah tersebut.

Berdasarkan hasil penelitian menunjukkan bahwa sebagian besar status kepemilikan lahan (43\%) dalam kategori tinggi atau milik sendiri. Ini berarti dengan lahan milik sendiri petani dapat mengatur lahan yang akan ditaman dengan komoditas yang diinginkan tanpa ada pengaruh atau perintah dari orang lain. Apabila petani menggarap lahan orang lain maka komoditas yang ditanam ditentukan berdasarkan kesepakatan antara pemilik lahan dan penggarap.

\section{Jarak Tempat Tinggal Ke pusat Kota (X5)}

Jarak tempat tinggal ke pusat kota di duga berhubungan dengan motivasi pemuda tani bekerja di sektor pertanian. Tempat tinggal pemuda tani yang dekat dari pusat perkotaan cendrung membuat pemuda tani memiliki motivasi yang rendah. Sebaliknya jarak tempat tinggal yang jauh dari pusat kota cenderung membuat pemuda tani memiliki motivasi yang tinggi untuk bekerja di sektor pertanian.

Sebagian besar jarak tempat tinggal responden ke pusat kota masuk dalam kategori sedang sebesar (62\%). Jarak ratarata tempat tinggal ke pusat kota yaitu sejauh $9 \mathrm{~km}$ dari tempat tinggal responden artinya, responden masih memungkinkan mengakses pekerjaan di luar sektor pertanian. Rekapitulasi deskripsi faktor-faktor yang diduga berhubungan dengan motivasi pemuda tani di sajikan pada Tabel 3 .
Tabel 3.

Deskripsi faktor-faktor yang diduga berhubungan dengan motivasi pemuda tani

\begin{tabular}{|c|c|c|}
\hline Variabel X & $\begin{array}{l}\text { Responden } \\
\text { Jumlah }\end{array}$ & $(\%)$ \\
\hline \multicolumn{3}{|l|}{ Pendidikan } \\
\hline Rendah & 9 & 42 \\
\hline Sedang & 21 & 25 \\
\hline Tinggi & 42 & 33 \\
\hline \multicolumn{3}{|l|}{ Pendapatan } \\
\hline Rendah & 29 & 42 \\
\hline Sedang & 18 & 25 \\
\hline Tinggi & 25 & 33 \\
\hline \multicolumn{3}{|l|}{ Luas lahan } \\
\hline Rendah & 33 & 46 \\
\hline Sedang & 16 & 22 \\
\hline Tinggi & 23 & 32 \\
\hline \multicolumn{3}{|c|}{ Status kepemilikan lahan } \\
\hline Garap & 15 & 21 \\
\hline Sewa & 26 & 36 \\
\hline Milik sendiri & 31 & 43 \\
\hline \multicolumn{3}{|c|}{ Jarak tempat tinggal ke pusat kota } \\
\hline Dekat & 7 & 10 \\
\hline Sedang & 45 & 62 \\
\hline Jauh & 20 & 28 \\
\hline
\end{tabular}

\section{Motivasi (Y)}

Motivasi merupakan suatu dorongan atau keinginan serta daya penggerak kemauan bekerja seseorang untuk memperoleh hasil yang ingin dicapai sebelumnya. Motivasi dapat menyebabkan petani bertindak dan berperilaku dengan cara tertentu. Motivasi menjadi semangat bekerja petani untuk memenuhi kebutuhan dan kepuasan meteril maupun non materil yang diperolehnya dari hasil kerja.

Seiring dengan kebutuhan kepuasan terdapat lima hirarki kebutuhan yang harus dipenuhi oleh manusia atau pemuda tani. Menurut Maslow ada kebutuhan yang paling dasar sampai kebutuhan yang paling tinggi yang harus dipenuhi yaitu kebutuhan fisiologis, kebutuhan rasa aman, kebutuhan sosial, kebutuhan penghargaan, dan kebutuhan aktualisasi diri. Motivasi pemuda tani bekerja di sektor pertanian dapat dilihat pada Tabel 4. 
Tabel 4.

Motivasi pemuda tani bekerja di sektor pertanian

\begin{tabular}{ccc}
\hline $\begin{array}{c}\text { Motivasi } \\
\text { (Skor) }\end{array}$ & Jumlah & $(\boldsymbol{\%})$ \\
\hline $32,110-39,689$ & 8 & 11 \\
$39,690-47,268$ & 29 & 40 \\
$47,269-54,847$ & 35 & 49 \\
\hline Jumlah & $\mathbf{7 2}$ & $\mathbf{1 0 0}$ \\
\hline
\end{tabular}

Berdasarkan Tabel 4 didapatkan motivasi pemuda tani tergolong dalam kategori tinggi. Artinya dorongan pemuda tani untuk bekerja di sektor pertanian masih baik. Hal ini ditunjukkan dari meskipun pendapatan responden diperoleh termasuk rendah namun responden tetap bekerja di sektor pertanian untuk memenuhi kebutuhan.

\section{Pengujian Hipotesis}

Hubungan antara variabel X (faktorfaktor yang berhubungan dengan motivasi petani) dengan variabel Y (tingkat motivasi petani) dalam penelitian ini menggunakan statistik non parametrik uji korelasi rank spearman dengan SPSS 25 (Statistical package for Social Science).

Tabel 5.

Hasil pengujian statistik faktor-faktor yang diduga berhungan dengan motivasi pemuda tani bekerja di sektor pertanian.

\begin{tabular}{lccc}
\hline \multicolumn{1}{c}{ Variabel X } & $\begin{array}{c}\text { Variabel } \\
\text { Y }\end{array}$ & $\begin{array}{c}\text { Koefisien } \\
\text { Korelasi }\end{array}$ & Sig. \\
\hline Pendidikan & & 0,595 & $0,000^{* *}$ \\
Pendapatan & & 0,288 & $0,014^{*}$ \\
Luas Lahan & & 0,292 & $0,013^{*}$ \\
Status & & & \\
$\begin{array}{l}\text { Kepemilikan } \\
\text { Lahan }\end{array}$ & Motivasi & 0,162 & $0,174^{\text {tn }}$ \\
Jarak & & & \\
Tempat & & & \\
Tinggal Ke & & & \\
Pusat Kota & & 0,033 & $0,785^{\text {tn }}$ \\
\hline
\end{tabular}

Keterangan:

** : corelation is sig at the 0,01 level (2-tailed)

* : corelation is sig t the 0,05 level (2-tailed)

tn : Tidak nyata

sig : signifikansi
Berdasarkan Tabel 5 diperoleh fakta variabel $\mathrm{X}$ yaitu pendidikan memiliki nilai signifikansi sebesar 0.001 lebih kecil dari $(\alpha)$ $=0,01$ atau $(99 \%)$, artinya terima $\mathrm{H} 1$ yang menunjukkan adanya hubungan yang sangat nyata antara pendidikan dengan motivasi pemuda tani bekerja di sektor pertanian. Variabel pendapatan dan luas lahan diperoleh nilai signifikansi sebesar 0,014 dan 0,013 lebih kecil dari $(\alpha)=0,05$ atau (95\%), artinya terima $\mathrm{H} 1$ yang menunjukkan adanya hubungan yang nyata antara pendapatan dan luas lahan dengan motivasi pemuda tani bekerja di sektor pertanian. Variabel kepemilikan lahan serta jarak pusat kota ke tempat tinggal memiliki nilai signifikansi sebesar 0,174 dan 0,785 lebih besar dari $(\alpha)$ $=0,05$ atau $(95 \%)$, artinya tolak H1 yang menyatakan tidak ada hubungan yang nyata dengan motivasi pemuda tani bekerja di sektor pertanian.

Hubungan antara Pendidikan dengan Motivasi Pemuda Tani

Pendidikan merupakan variabel (X) yang diduga memiliki hubungan nyata dengan motivasi pemuda tani. Hasil pengujian hipotesis hubungan antara pendidikan dengan motivasi pemuda tani. diperoleh signifikansi sebesar 0,001, hal ini menjelaskan bahwa signifikansi sebesar $\alpha$ 0,01 yang berarti terima $\mathrm{H} 1$, yaitu adanya korelasi sangat nyata pada taraf kepercayaan (99\%). Hal ini sejalan dengan penelitian yang dilakukan Kusuma, Sriyoto, dan Priyono (2015) yang menyatakan ada hubungan yang nyata antara pendidikan dengan motivasi petani dalam kegiatan usahatani dalam penggunaan benih hibrida.

Tingkat pendidikan petani dapat mengubah pola pikir yang lebih baik, sehingga semakin rasional daya pikir yang mampu dicapai pemuda tani. Responden yang berpendidikan rendah menyebabkan sedikitnya pengetahuan dan keahlian yang dimiliki. Namun hubungan sosial yang baik dengan masyarakat membantu responden dalam mendapatkan informasi ataupun pengetahuan secara langsung terkait pertanian. 


\section{Hubungan antara Pendapatan dengan Motivasi Pemuda Tani}

Tingkat pendapatan pemuda tani dalam penelitian ini merupakan variabel $(\mathrm{X})$ Faktor Penunjang perekonomian yang penting yaitu pendapatan. Hasil pengujian hipotesis menunjukkan bahwa antara pendapatan pemuda tani dengan motivasi pemuda tani bekerja di sektor pertanian diperoleh hasil signifikansi sebesar 0,014 lebih kecil dari $(\alpha)$ $=0,05$, artinya terima $\mathrm{H} 1$ yang menunjukkan adanya korelasi atau hubungan yang nyata antara pendapatan dengan motivasi pada taraf kepercayaan $(95 \%)$.

Penelitian ini sejalan dengan penelitian yang dilakukan oleh kus (2015) yang menyatakan bahwa pendapatan berhubungan dengan motivasi pemuda tani melanjutkan usahatani. Kondisi ini membuktikan bahwa semakin tinggi pendapatan maka motivasi untuk bekerja di sektor pertanian semakin tinggi. Pendapatan dapat memenuhi kebutuhan petani.

\section{Hubungan antara Luas Lahan dengan Motivasi Pemuda Tani}

Luas lahan pada penelitian ini merupakan variabel (X) yang diduga berhubungan dengan motivasi pemuda tani bekerja di sekotor pertanian. Pengujian hipotesis menunjukkan bahwa korelasi antara luas lahan dengan motivasi pemuda tani diperoleh hasil signifikansi sebesar 0,013 lebih kecil dari nilai $(\alpha)=0,05$, artinya terima $\mathrm{H} 1$.

Menunjukkan adanya hubungan yang nyata pada taraf kepercayan $(95 \%)$ antara luas lahan dengan motivasi pemuda tani bekerja di sektor pertanian. Penelitian ini sesuai dengan penelitian Marza (2018) yaitu luas lahan berhubungan dengan motivasi pemuda tani dalam melanjutkan usahatani.

\section{Hubungan antara Status Kepemilikan Lahan dengan Motivasi Pemuda Tani}

Pengujian hipotesis menunjukkan bahwa hubungan antara status kepemilikan lahan dengan motivasi pemuda tani bekerja di sektor pertanian diperoleh nilai signifikansi sebesar 0,174 lebih besar dari $(\alpha)$ $=0,05$, artinya tolak $\mathrm{H} 1$ yang menunjukkan tidak terdapat korelasi atau hubungan antara status kepemilikan lahan dengan motivasi pemuda tani bekerja di sektor pertanian pada taraf kepercayan (95\%). Penelitian ini sejalan dengan penelitian yang dilakukan oleh Marza (2018) yang menyatakan bahwa status kepemilikan lahan tidak berhubungan nyata dengan motivasi petani dalam melanjukkan usahatani.

Pemuda tani yang menggarap lahan akan lebih giat dalam menjalankan usahanya karena hasil yang diperoleh akan dibagi dengan pemilik lahan apabila petani tidak serius dalam menjalankan usahatani maka bisa saja lahan tersebut di ambil oleh pemilik lahan.

Hubungan antara Jarak Tempat Tinggal ke Pusat Kota dengan Motivasi Pemuda Tani

Hasil pengujian hipotesis menunjukkan bahwa jarak tempat tinggl ke pusat kota dengan motivasi pemuda tani bekerja di sektor pertanian diperoleh nilai signifikansi sebesar 0,785 lebih besar dari nilai $(\alpha)=0,05$, artiya tolak $\mathrm{H} 1$, yaitu tidak terdapat hubungan yang nyata antara jarak tempat tinggal ke pusat kota dengan motivasi pemuda tani bekerja di sektor pertanian. Marza (2018) melakukan penelitan dengan hasil tidak ada hubungan yang nyata antara jarak tempat tinggal responden dengan motivasi pemuda tani.

\section{SIMPULAN}

Tingkat motivasi pemuda tani bekerja di sektor pertanian masuk kategori tinggi di Pekon Padang Cahya, Kecamatan Balik Bukit, Kabupaten Lampung Barat. Faktorfaktor yang berhubungan dengan motivasi pemuda tani bekerja di sektor pertanian yaitu pendidikan (X1), pendapatan (X2), dan luas lahan (X3). 


\section{DAFTAR PUSTAKA}

BPS Kabupaten Lampung Barat. (2018) Lampung Barat dalam Angka 2018. Www.bps.go.id ( Nov. 18, 2018).

Fitriayani, A., Hasanuddin, T., dan Viantimala, B. (2019). Kinerja penyuluh pertanian, kepuasan petani, dan produktivitas usahatani jagung di Kecamatan Natar, Kabupaten Lampung Selatan. Jurnal suluh pembangunan, 1(2), 134-141.

Hasanuddin, T., dan Viantimla, B. (2011). Motivasi Petani Beralih Komoditas Usahatani. In Seminar Nasional Sains dan teknologi IV. Bandar Lampung.

Kusuma, Ayu., sriyoto, dan priyono, B. (2015). Faktor yang Berhubungan dengan Motivasi Hasil Panen Padi Petani di Kabupaten Seluma. AGISEP, 14(1), 108-119

Marza, A., R, (2018). Faktor-Faktor yang Mempengaruhi Minat Pemuda Pedesaan dalam Melanjutkan Usahatani Padi di Kabupaten Lampung Tengah.
Mayasari K, U Sante, dan C Ammatilah. 2015. Analisis Motivasi Petani dalam Mengembangkan Pertanian Perkotaan di Provinsi DKI Jakarta. Jurnal Buletin Pertanian Perkotaan,5(1).

Natanael, S. 2013. Mahir Menggunakan SPSS Secara Otodidak. PT. Elex Media Komputindi, Jakarta.

Nisa, N. K., dan Zain. (2015). Motivasi Petani dalam Menanam Komoditas pada Daerah Lumbung Padi di Kabupaten Gresik. Jurnal Swara Bhumi, 3(3).

Nugroho D Agus, Waluyati R.W, dan Jamhari. (2018). Upaya Memikat Generasi Muda Bekerja pada Sektor Pertanian di Daerah Istimewa Yogyakarta. Jurnal Ilmu Pemerintahan dan Sosial Politik UMA, 6(1), 76-95.

Reksohadiprojo, S, dan Handoko, H. (2001). Organisasi Perusahaan Teori Struktur danPerilaku. BPFE, Yogyakarta.

Sugiyono. (2010). Statistika Penelitian. Alfabeta, Bandung. 